\title{
WRITING CHEMICAL FORMULAS AND REACTION EQUATIONS: THE HISTORY AND PRACTICE OF BUILDING BLOCK METHOD
}

\author{
Algirdas Sulcius \\ Kaunas University of Technology, Lithuania \\ Sergey Teleshov \\ Secondary school № 635, Saint Petersburg, Russian \\ Federation
}

\begin{abstract}
One of the most difficult elements for students in chemistry is writing and balancing equations of chemical reactions. The aim of this research was to investigate the ability of the 8-9th grade students to write chemical formulas and equations of reactions. Verhovskij's method, which involves using white and full-colour paper cards, was proposed as a chemistry teaching method for students. Some of the students suggested using non-paper-based cards, i.e. "domino sticks". The obtained results proved that students who had participated in the building blocks activity showed significantly higher post-test scores than students who had not participated. The average grade of the students who used the cards for chemical formula formation and reaction equations increased respectively by 1.30 and 1.20. The average grade for writing and balancing of the reactions equations was lower because balancing requires strong knowledge in mathematics. The results have shown that the use of cards is a good method at an early stage of chemistry education.
\end{abstract}

Keywords: general chemistry, hands-on learning, domino-stick, graphical formula, reaction equation.

\section{Introduction}

Chemistry is considered as one of the most demanding school subjects and most of the students find chemistry difficult. Chemistry is based on concepts, many of which are abstract and hard to learn. When studying chemistry in Lithuanian and Russian schools in the 8th grade (Teleshov, Teleshova, Bílek, Gorskis, Lavonen, Töldsepp, Svirksts, \& Sulcius, 2014), students rarely encounter difficulties in understanding the subject, as the topics of the 8th grade chemistry course are simple, relate to the topics heard in the lower classes, especially with the subject of physics in the 7th grade course. It is more difficult for students to understand chemistry in the 9th grade, as they move from common natural sciences to the specific concepts, equations of reactions, and problem solving.

\section{Research Focus}

One task that seems difficult and is highly important for many of today's students starting chemistry studies is writing chemical formulas (Stone, 1944), predicting the products of chemical reactions and writing net ionic equations to represent them. In Russia and Lithuania in the 8-9th grades, it is important for students to understand that each chemical formula describes the chemical composition of a given substance, and that chemical transformations take place according to the defined laws because their perception determines whether students will learn chemistry in the future. In the process of learning 
chemistry, especially in the 8-9th grades, it is important to teach students to write and balance equations of chemical reactions (Agarwal, 2004). Writing chemical reaction equations often causes many difficulties because students do not understand the meaning of chemical symbols (Hsin-kai Wu, Krajcik, \& Soloway, 2001) and students learn chemical formulas by heart. Although they are able to recognize them, they often do not understand their meaning. Students' misconceptions and difficulties in writing balanced equations for ionic compounds soluble in water have been identified (Naah, \& Sanger 2012). When these topics are taught from the textbook without demonstrations, it is understandable that students lack interest in them. In order to avoid this and to interest the students, varieties of promotional methods are used:

- "crisscross" method (Tro, 2011),

- clip clues (Carmen, \& Mason, 2008),

- ion card cut-outs (Chimeno, Wulfsberg, Sanger, \& Melton, 2006),

- LEGO blocks (Sharma, 2001; Ruddick, \& Parryl, 2012),

- sticky ions (Ryan, \& Herrington, 2014),

- writing of chemical formulas using a magnetic board and common magnetic letters and numbers for blind students (Boyd-Kimball, 2012).

It has been stated (Cook, 2006) that virtual demonstrations play an essential role in sharing ideas in science education. Real and virtual laboratory works equally reveal students' effort in order to work properly, consistently and in an organized manner, but through virtual laboratory work, students have the ability to get the result by guessing because they can repeat chemical tests many times with different reagents and that reduces the effectiveness of learning (Voronovic, 2013). According to the level of the interest for them, the students have arranged the tests in the following order: 1) real tests; 2) real-time filming; 3) virtual computer-based tests (Voronovic, 2013).

Application of history of teaching methods in chemistry allows any teacher to avoid discovering many of the methods used already and apply them more productively to their pedagogical purposes. It is often said that the newly discovered methods and techniques had been already known for a long time before us, just forgotten. Therefore, information about the scientist who created the method that helps students to learn to write formulas of ionic compounds and reaction equations is herein introduced to the readers.

In 1927, the first two editions of "Chemical alphabet" (Verhovskij, 1927), based solely on his experience as a secondary school teacher (Figure 1), were published. 

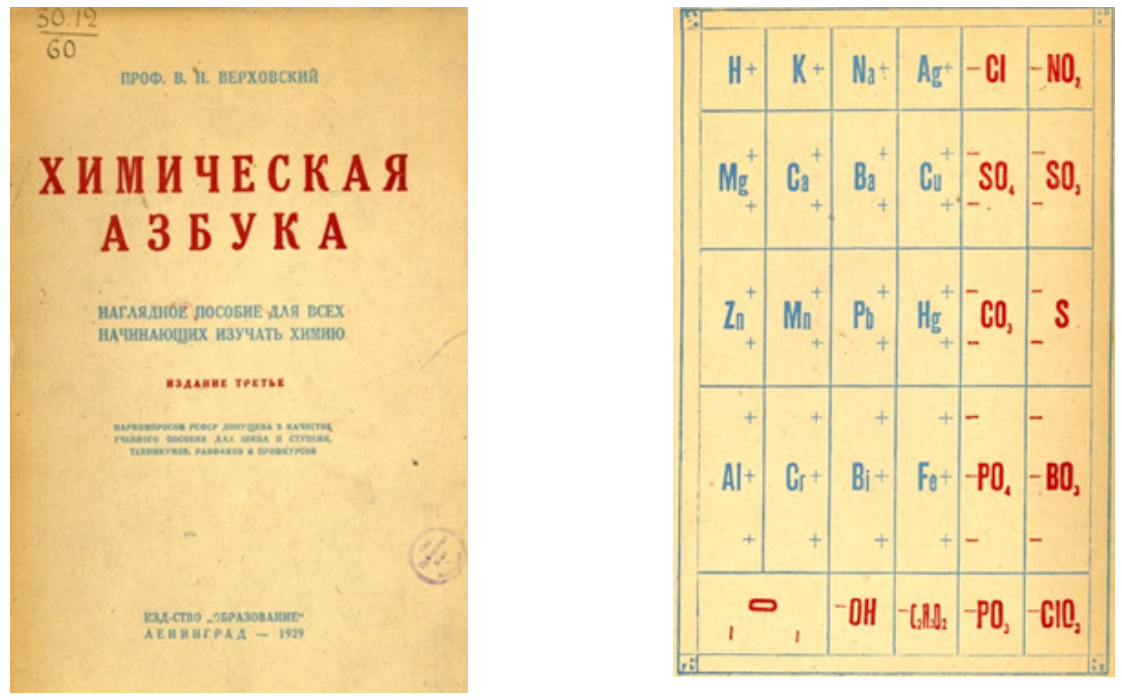

Figure 1. Copies of some pages from original book "Chemical alphabet" (Verhovskij, 1927).

What was the novelty of the methodical medium? In 1927, N. Verhovskij noted: "Beginner in the chemistry studies has to step over one difficulty of not learning chemistry by heart, but being able to write and balance chemical formulas and equations knowledgeably" (p. 4). In the studies of chemistry, it is important not to learn by memorizing, but gain the ability to construct formulas and equations. Developing of this ability requires exercising only and one should not spare time for this exercise. This time is not lost.

N. Verhovskij emphasized in "Chemical alphabet", that the most productive writing of the equations for reactions should be when it is done:

1) after studying the text of the tutorial;

2) after performing experiments on the properties of oxides, acids, bases, and salts.

"Chemical alphabet", includes a set of cards, as well as guidelines, not only for teachers, but also for the students (Table 1). Working with the alphabet would give the desired effect only when the material is enough to learn to solve the tasks. The exercises must not teach the properties of substances and conditions of reactions. The exercises should not take too much time.

To validate these observations, students were asked to perform:

- 17 different exercises on drawing up formulas of acids and salts (Figure 2 A-B);

- 15 exercises related to oxides and their hydrates;

- 47 exercises on a chemical reactions of formation of salts (Figure $2 \mathrm{C}$ );

- 5 exercises on chemical reactions of basic salts formed during the hydrolysis of these salts. 
Table 1. Instructions of "Chemical alphabet".

\begin{tabular}{|c|c|}
\hline Instructions for students & Instructions for teachers \\
\hline $\begin{array}{l}\text { 1. The alphabet is the exercise in creating formulas } \\
\text { only, rather than studying chemistry. } \\
\text { 2. Cards should be placed so that the plus signs } \\
\text { always fully coincide with the minus signs. There } \\
\text { should not be free pluses or free minuses. } \\
\text { 3. Card sizes and number of plus signs correspond } \\
\text { to the valence of metals, and the number of minus } \\
\text { signs represents valence balances or the basicity } \\
\text { of the acids. } \\
\text { 4. Each folded formula or chemical equation } \\
\text { should be written in a notebook. }\end{array}$ & $\begin{array}{l}\text { 1. A student must learn that the chemical- } \\
\text { technical formulas and equalities do not require } \\
\text { memorization - he/she is able to make them. } \\
\text { 2. Continually teach children to create formulas } \\
\text { and write chemical equations - these exercises are } \\
\text { similar to problem solving in mathematics. } \\
\text { 3. Spend less time on the mechanical side. The } \\
\text { principle of visibility is important. The alphabet } \\
\text { has been created for this purpose. } \\
\text { 4. Remember that the cards represent only the } \\
\text { conditional notation of the valence and the } \\
\text { basicity. This is a mnemonic technique. } \\
\text { 5. Encourage students to turn over the cards and } \\
\text { check the information on the reverse side. By } \\
\text { doing this, a student remembers quicker the signs } \\
\text { and the elements of the formula (Figure } 2 \mathrm{C} \text { ). } \\
\text { 6. A student is ready for the possible future topic of } \\
\text { electrolytic dissociation; he/she can easily adopt } \\
\text { the language of the ions. } \\
\text { 7. When writing the formulas and chemical } \\
\text { equations be sure that students have learned the } \\
\text { topic "Oxides, acids and salts" in the laboratory } \\
\text { and have a required knowledge about them. The } \\
\text { alphabet is used only for the exercising. } \\
\text { 8. The alphabet should be used also while doing } \\
\text { laboratory works. } \\
\text { 9. It is essential that students not only arrange the } \\
\text { formulas and chemical equations, but also write } \\
\text { them in notebooks. }\end{array}$ \\
\hline
\end{tabular}

It is difficult to align the paper cards by hand, one next to the other. Therefore, in 1930s prof. P. Lebedev (Lebedev, 1931) perfected Verhovskij's cards, which allowed the more accurate combination of ions to each other by writing the graphical formulas (Figure 3). This was the prototype of the LEGO blocks. After 90 years, the improved Lebedev's cards were used in the modern Russian school textbook (Eremin, Drozdov, Kuz'menko \& Lunin, 2004). Unfortunately, the textbook did not contain the ions charges, what reduced the methodological value of the cards. 

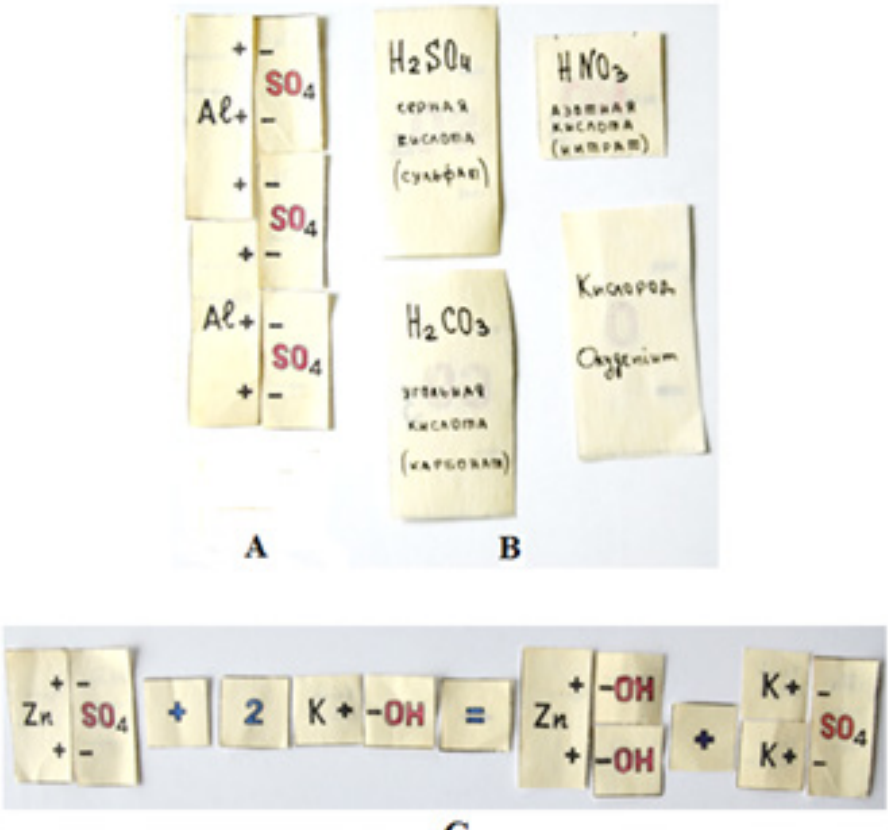

C

Figure 2. The graphical formula of $\mathrm{Al}_{2}\left(\mathrm{SO}_{4}\right)_{3}(\mathrm{~A})$, reverse side of some cards (B) and the example of the chemical reaction $(\mathrm{C})$.
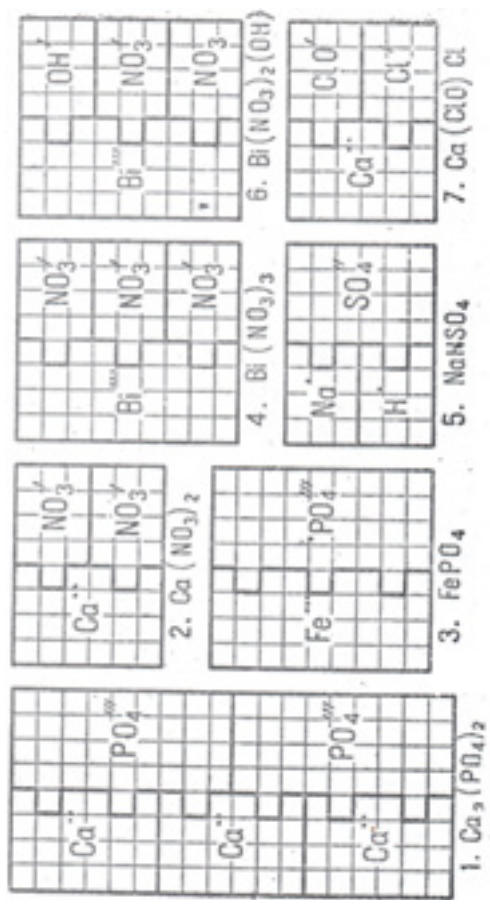

Figure 3. Original paper cards of graphical formulas, which were the prototype of LEGO blocks. 


\section{Research Aim}

The aim of this research was to investigate the ability of the 8-9th grade students to write chemical formulas and equations of reactions. Research question was formulated: can the use of cards help students to write chemical formulas and chemical equations?

\section{Research Methodology}

\section{Research Description and Data Analysis}

This research was carried out in 2015/2017 school year. Ninety-six Russian and Lithuanian students (four classes) participated in the study (14-15 years old) in the 2015/17 school years. The students were tested in classes as they were already divided in schools without paying attention to distribution by gender. Students were tested by Verhovskij's method, using self-made cards. The research tool was a question sheet (Appendix) consisting of two groups, which each consisted of three questions, and test duration time was 45 minutes. Using colourless/coloured ion cards, students had to form chemical formulas and chemical reaction equations and then write them down on a piece of paper. The overall score was 10 points for each question group. Students were warned they would get 0 points if they used pencil instead of ball-point pen.

\section{Research Results}

Students were introduced to Verhovskij's method. For the better retention, some students made cards of the cations and anions not from white paper, but from the coloured one (Figure 4A): red colour for cations and blue one for anions. Some of the students made coloured ions (called domino sticks), which made combining graphical formulas or reaction equations much easier (Figure 4B). Students were very interested in using domino sticks since they made them themselves and these cards touchable by hands. Whereas, virtual cards or games cannot be touched by students and students forget them quickly.

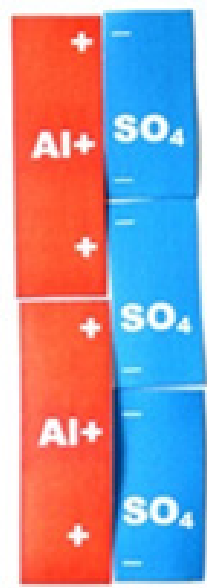

$\mathbf{A}$

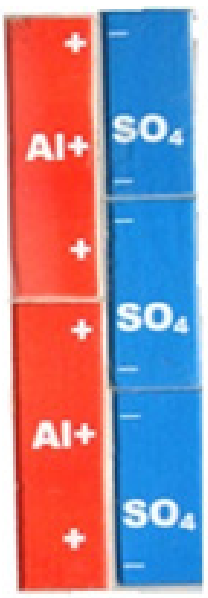

B

Figure 4. Colour cards (A) and domino sticks (B) of graphical formula of $\mathrm{Al}_{2}\left(\mathrm{SO}_{4}\right)_{3}$. 
The average point scores of students without using and using cards are presented in Figure 5. As seen, in both cases (chemical formula formation and reaction equations) the average grade of the students using the cards increased by 1.30 and 1.20 , respectively. The average grade of student grade using the cards for writing and balancing reaction equations is lower because balancing requires strong knowledge in mathematics.
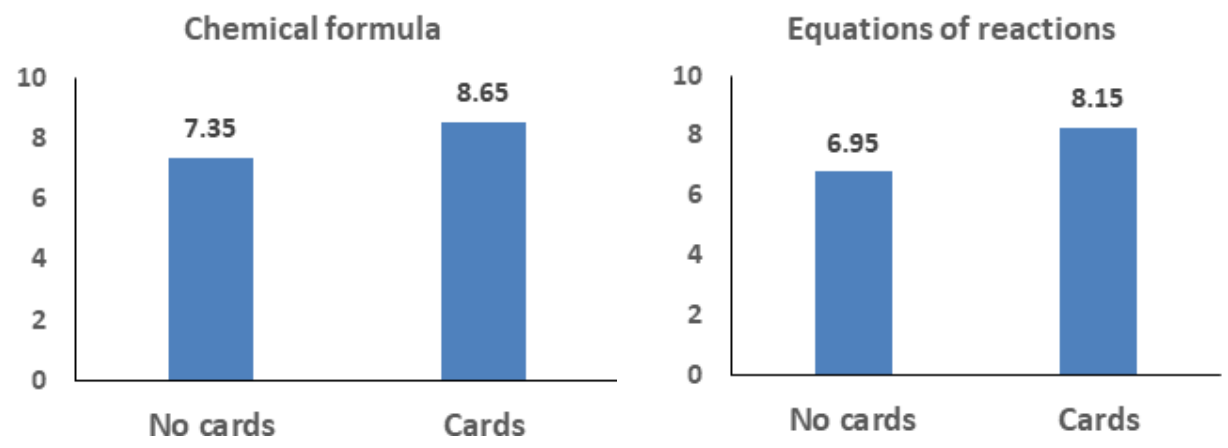

Figure 5. The average point score obtained by the respondents in particular point ranges.

In secondary Russian school, students made several cards from thick paper and glued them to the backside of the big sand emery paper (nowadays Velcro could be used). Students lined up in front of the class with the cards attached to their clothes (Figure 6) and represented the formula that everyone else recorded in the notebooks. Students loved this game.
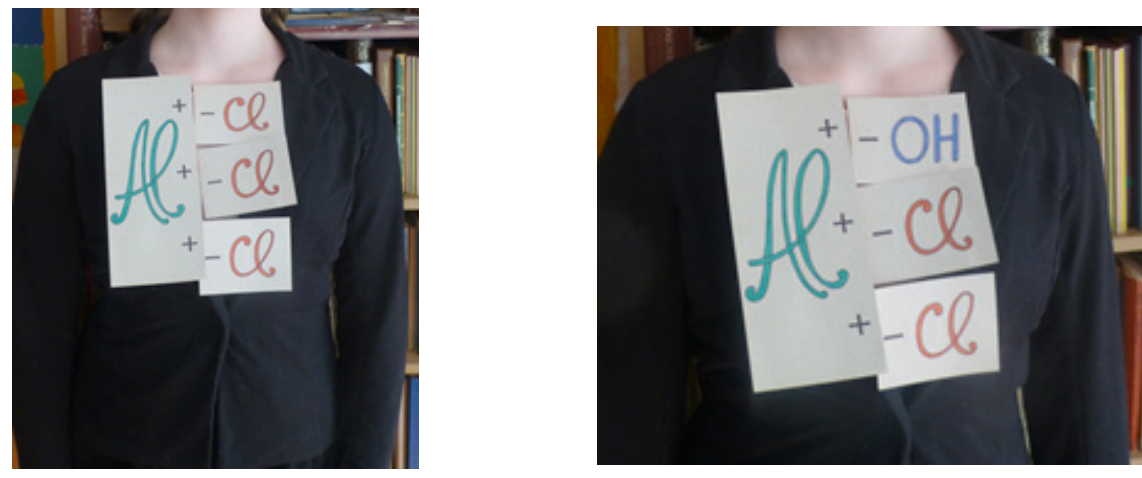

Figure 6. Students' clothes with attached cards of graphical formulas.

In 2019, the new chemical tool Chem Tokens is being offered to chemistry teachers on the website of the Lithuanian Association of Chemistry Teachers. It should be noted, that Chem Tokens is an innovative teaching tool that combines the augmented reality with physical experience during chemistry lessons. In fact, this is an innovative version of the Verhovskij's method. 


\section{Conclusions}

Chemistry teachers say that in the 8-9th grades the most difficult questions for students are writing chemical formulas and chemical reactions. Research was aimed at investigation of the ability of the 8-9th grade students to improve skills on these issues using self-made colourless/coloured ion cards and domino sticks. This research was accomplished in Russian and Lithuanian schools during 2015/17 years. It is worth mentioning that students from two countries were tested with an age gap of one year. Research has revealed the effectiveness of the use of cards in secondary school. The average grade of the students using the cards increased by 1.30 and 1.20 (chemical formula formation and reaction equations, respectively). In the subsequent chemical education, these 8-9th grade students should have had fewer problems with writing chemical formulas and balancing chemical reactions.

\section{References}

Agarwal, D. D. (2004). Modern methods of teaching chemistry. New Delhi: Sarup Sons, p. 196.

Boyd-Kimball, D. (2012). Adaptive instructional aids for teaching a blind student in a nonmajors college chemistry course. Journal of Chemical Education, 89(11), 1395-1399.

Carmen, F., \& Mason, D. (2008). Clip clues: Discovering chemical formulas. Journal of Chemical Education, 85(12), 1648A-1648B.

Chimeno, J. S., Wulfsberg, G. P., Sanger, M. J., \& Melton, T. J. (2006). The rainbow wheel and rainbow matrix: Two effective tools for learning ionic nomenclature. Journal of Chemical Education, 83(4), 651-654.

Cook, M. P. (2006). Visual representations in science education: The influence of prior knowledge and cognitive load theory on instructional design principles. Science Education, 90(6), 10731091.

Eremin, V. V., Drozdov, A. A., Kuz'menko, N. E., \& Lunin, V. V. (2004). Himija. 8 klass, Moskva: ONIKS 21 vek, 303.

Hsin-kai Wu, Krajcik, J. S; Soloway, E. (2001). Promoting understanding of chemical representations: Students' use of a visualization tool in classroom. Journal of Research in Science Teaching, 38 (7), 821-842.

Lebedev, P. P. (1931). Kurs opytnoj himii. Moskva-Leningrad: Gosizdat, c. 379.

Naah, B. M., \& Sanger, M. J. (2012). Student misconceptions in writing balanced equations for dissolving ionic compounds in water. Chemistry Education Research and Practice, 13(3), 186-194.

Ryan, S., \& Herrington, D. B. (2014). Sticky ions: A student-centered activity using magnetic models to explore the dissolving of ionic compounds. Journal of Chemical Education, 91(6), 860-863.

Ruddick, K. R., \& Parryl, A. B. (2012). JCE Classroom activity \#113: An interlocking building block activity in writing formulas of ionic compounds. Journal of Chemical Education, 89(11), 1436-1438.

Stone, C. H. (1944). The teaching of equations. Journal of Chemical Education, 10, 550-551.

Sharma, C. V. K. (2001). Designing advanced materials as simple as assembling lego blocks. Journal of Chemical Education, 78(5), 617-622.

Teleshov, S., Teleshova, E., Bílek, M., Gorskis, M., Lavonen, J., Töldsepp, A., Svirksts, J., \& Sulcius, A. (2014). To a question about the possibility of creation of uniform educational standards in chemistry (comparison attempt). Research, theory and practice in chemistry didactics. Science and technology education for the 21st century: proceedings of the 23rd international conference on Chemistry Education and 9th Regional IOSTE Symposium for Central and Eastern Europe (pp. 130-140). Hradec Kralove, Czechia. 
Tro, N. J. (2011). Unit 6. In introductory chemistry, 4th ed.; Prentice Hall: Upper Saddle River, NJ. Voronovic, R. (2013). Education of pupils' cognitive skills through application of virtual and real experiments during chemistry lessons. Vilnius: VU, p. 204.

Verhovskij, V. N. (1927-1929). Himicheskaja Azbuka. Nagljadnoe posobie dlja vseh nachinajuschih izuchat' himiju. Leningrad: Obrazovanie, 16.

\section{Appendix}

\section{Sample of question sheet}

1. Write the chemical formula: aluminium sulphate, barium nitrate and carbonic acid.

2. Write and balance the reactions equations:

$$
\begin{gathered}
\mathrm{ZnSO}_{4}+\mathrm{KOH} \rightarrow \\
\mathrm{Al}_{2}\left(\mathrm{SO}_{4}\right)_{3}+\mathrm{NaOH} \rightarrow \\
\mathrm{K}_{2} \mathrm{CO}_{3}+\mathrm{H}_{2} \mathrm{SO}_{4} \rightarrow
\end{gathered}
$$

Received 25 April 2019; Accepted 18 June 2019

\section{$\square$}

PhD., Professor, Kaunas University of Technology, Kaunas, Lithuania.

E-mail: algirdas.sulcius@ktu.lt

\section{Sergey Teleshov}

Teacher, Secondary school № 635, Saint Petersburg, Russian Federation.

E-mail: histmetodik@mail.ru 